\title{
Development of Media Game on Acid-Base Material and its Effect on Self- Regulated Learning
}

\author{
Ikfisani Yuniar Rifki, *Achmad Lutfi \\ Chemistry Education Department, Faculty of Mathematics and Science Education, State \\ University of Surabaya. Ketintang Campus, Surabaya, 60231, Indonesia \\ *Corresponding Author e-mail: achmadlutfi@unesa.ac.id
}

Received: January 2022; Revised: January 2022; Published: January 2022

\begin{abstract}
This study aimed to obtain an Android-based chemistry racing challenge game as a learning media for acid-base materials that are valid, practical, and effective to facilitate students' self-regulated learning. The research method used is research and development (R\&D). The instruments used are validation sheets, student response questionnaire sheets, self-regulated learning questionnaire sheets, and test question sheets. The research subjects were 18 students of SMA Muhammadiyah 2 Sidoarjo. The validation results get a score mode of $\geq 3$ with a good category. The practicality test scored $\geq 61 \%$ for each goal with a very practical category. The effectiveness of games as learning media is seen from student learning outcomes and self-regulated learning. The classical completeness achieved is $61 \%$, and students' self-regulated learning achieved $\geq 80.1 \%$ with a very good category. Thus, it can be concluded that the Chemistry Racing Challenge game is valid, practical and effective as a game learning media.
\end{abstract}

Keywords: Learning Media, acid-base, self-regulated learning, chemistry racing challenge

How to Cite: Rifki, I., \& Lutfi, A. (2022). Development of Media Game on Acid-Base Material and Its Effect on Self-Regulated Learning. Prisma Sains : Jurnal Pengkajian Ilmu dan Pembelajaran Matematika dan IPA IKIP Mataram, 10(1), 57-68. doi:https://doi.org/10.33394/j-ps.v10i1.4764

https://doi.org/10.33394/j-ps.v10i1.4764

Copyright $\odot$ 2022, Rifki \& Lutfi This is an open-access article under the CC-BY License.

\section{INTRODUCTION}

One of the natural sciences (IPA) is chemistry seen as a process and a product. Scientific activities to perfect knowledge and discover new knowledge in chemistry are referred to as the process. While, the meaning as a product is a process of facts, concepts, principles and laws, and theories of chemical scientists' findings (Hemayanti et al., 2020). Chemistry can not be separated in everyday life. In life, chemistry is always involved in the process. Studying the structure and properties of natural and synthetic materials and their benefits is beneficial when studying chemistry (Merdekawati, 2013). This knowledge can be applied in life to learn more about the structure and energy in a matter to improve the quality of human resources. So it can be concluded that studying chemistry is very important.

Based on research, Sahlan (2016) said that chemistry is considered difficult to understand among high school students because basic concepts must be involved in solving problems in chemistry. Students still find it difficult to learn chemistry because they often face certain formulas in solving problems and memorizing them. But in reality, students often misuse the chemical formula according to its designation. The lack of students' understanding of the concepts being taught makes it challenging to understand acid-base material.

Sahlan's (2016) research on students' chemistry learning outcomes on daily tests shows that the incompleteness value of acid-base materials is relatively high, with a percentage of $41.33 \%$. In addition, information was obtained that the material for acid-base theory, acid-base indicators, and $\mathrm{pH}$ calculations were the materials considered the most difficult by students. 
The length of time students marks this difficulty in understanding acid-base theoretical material, indicators of acid-base solutions, and $\mathrm{pH}$ of acid-base solutions when explained by the teacher. In addition, in working on the daily test questions, most students experienced errors on acid-base theory questions, acid-base indicators, and calculation of solution $\mathrm{pH}$ (Sahlan et al., 2016).

One factor that makes chemistry learning unattractive is the media used, which is less attractive to students' motivation to learn. The right media is needed to receive the subject matter well to minimize students' difficulties in studying acid-base material. Using engaging media can increase student interest and foster motivation to learn. Permendikbud No. 65 of 2013 states that learning media in the form of a learning process aids in delivering subject matter. In this case, it can be packaged into a game form as a learning media that can attract students' attention. Learning media that present games, supported by color displays, pictures, or videos, can increase students' interest in learning. So that indirectly, students carry out an activity, namely playing while learning, where children will learn while playing (Lutfi \& Hidayah, 2019). In addition, interactive learning media makes learning more interesting and not monotonous (Maharani \& Asyhari, 2020).

With the game as a learning tool, the game that initially had a negative impact became something exciting and valuable as a learning tool for students. These negative impacts have to be overcome and minimized by developing games for learning media. A game as a learning media, which initially had a negative effect, will become more fun and useful as a means of learning media for students (Hidayah \& Rahmanah, 2019).

The development of increasingly new and rapid technology has an impact and a foundation for studying communication. The use of media, smartphones and the internet is needed to study and seek various information from various circles, such as job seekers, students, students doing assignments, and the general public. The development of science and technology is increasingly encouraging efforts towards using technological results in an innovative way in students' learning performance. One of the educational program efforts is to develop appropriate technology-based learning when educators provide material. The use of learning media determines students' understanding of the material presented. The 21 st century has implemented android-based learning media as a learning style. Digital games will immerse students in game situations, increase learning motivation, increase learning effectiveness, and encourage them to express thoughts and emotions (Chuang \& Chen, 2007).

In addition to the learning media used in the learning process, the determinant of student success is self-regulated learning (SRL). According to Zimmerman, self-regulated learning is a process where students know their learning goals and try to control, process and control motivation, cognition, and behavior to achieve the goals that have been made (Rosito, 2018). According to Boekaerts (2006), the ability to regulate one's learning is the key to successful learning. Some experts say that students' low motivation, ineffective strategies, and low selfregulation affect students' low academic achievement.

When students can control the ability of self-regulated learning, then the goals that have been set can be achieved. According to Locke and Lathan, learning objectives can determine the learning outcomes that students want to achieve. This thing is confirmed by Persico \& Steffens (2017) that students will get high learning outcomes if self-regulation can be controlled. Thus the self-regulated ability learning of students can affect learning outcomes.

Yulianti (2016) found a significant difference between students' self-regulated learning with high learning outcomes and students with low learning outcomes. This statement is supported by Mustika and Khoirunnisa (2016) research, which states that students who have high self-regulated learning will easily accept the material.

There are a lot of online games in various circles today. Various kinds of game themes can already be found that are entertaining. Games that contain educational elements are also 
no less important to develop. One of them is the Chemistry racing challenge. Chemistry Racing Challenge (CRC) game is an Android-based adventure-themed game. This game is also designed to be operated via a computer to make it easier. CRC tells the story of a motorcycle racer who gets lost in the world of chemistry. Players take on the role of a lost motorbike racer and must complete a mission to answer five questions from each level to return to the match. Games are played individually. There are several menus in the CRC, including the competency menu, game rules, material, and play. Before entering the main menu, players can first understand acid-base materials by going to the material menu. CRC has four levels with different backgrounds. Questions at level 1 have a cognitive level of $\mathrm{C} 2$, level 2 questions have a cognitive level of $\mathrm{C} 3$, level 3 has a cognitive level of $\mathrm{C} 4$, and level 4 contains questions with various levels of cognitive domains. The challenge of this game, the player must be able to balance his motorbike while passing through a sloping or steep track and obstacles that block the road. Players can answer at least three questions correctly to proceed to the next level and get a minimum score of 550 points. When players have difficulty answering each question, there is a help feature in a key icon where players get a small clue to answer the question. This feature can also bring students back to the material menu to understand the material again to answer already available questions.

Based on the description above, it is necessary to develop a racing challenge chemistry game suitable for use as a media of chemistry learning on acid-base materials and the impact of SRL after using the game learning media. This research aims to know the feasibility is viewed based on aspects of validity that refer to content validity and construct validity, practicality refers to user response, and effectiveness refers to learning outcomes and selfregulated learning.

\section{METHOD}

This research uses research and development methods ( $R \& D$ ). The $R \& D$ research method is used to produce certain products and test the effectiveness of certain products (Sugiyono, 2016). There are ten steps used in this R\&D method, namely potential and problems, data collection, product design, design validation, design revision, product trials, product revisions, usage trials, product revisions, and mass production of products. This research only uses the ten steps until the sixth step, namely product testing, because it is only to determine the feasibility. The $R \& D$ research scheme, according to Sugiyono, is presented in Figure 1.

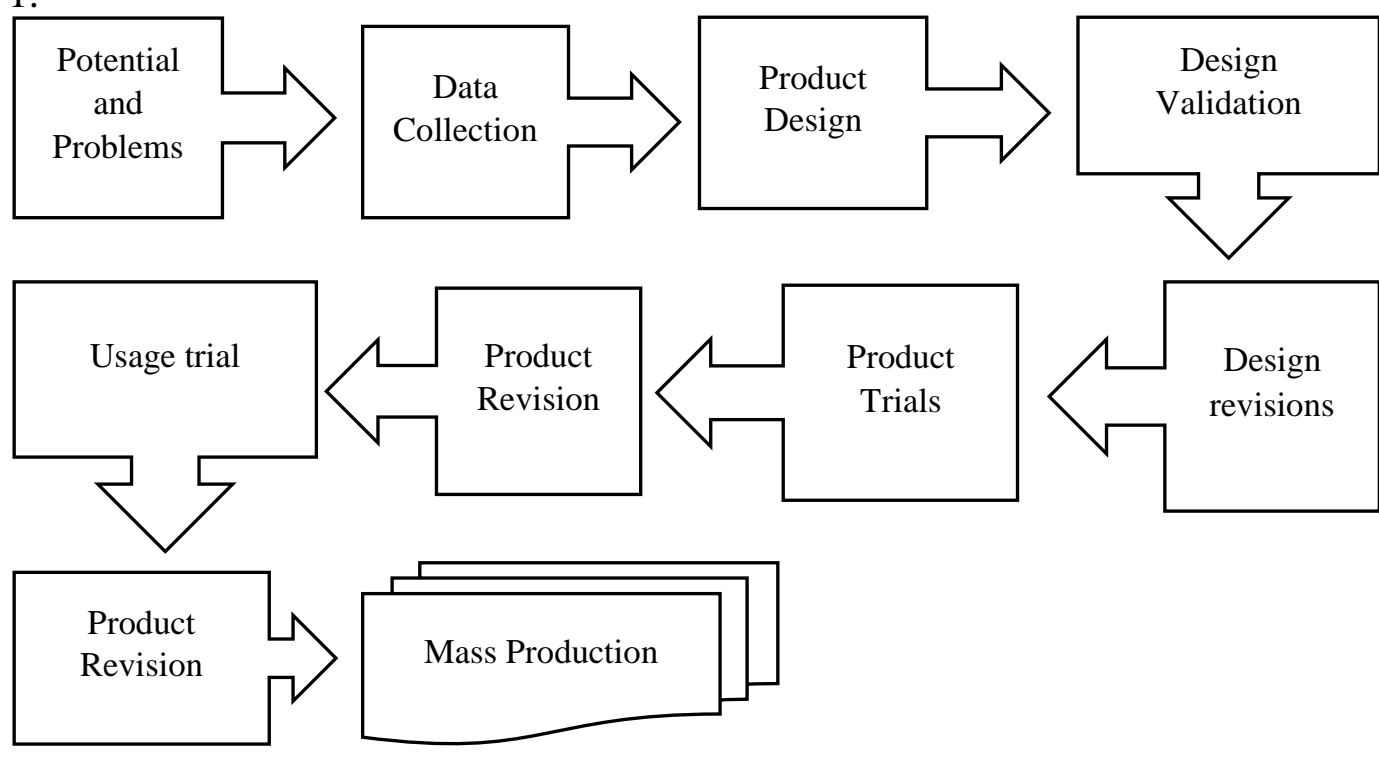

Figure 1. The Steps for Using the R\&D Method 
The trial was conducted in class XI MIPA on 18 SMA Muhammadiyah 2 Sidoarjo, East Java. The Chemistry Racing Challenge game was tested on a limited basis using a one-group pretest-posttest design. The experiment was carried out in one group without a comparison group, with the following scheme.

\section{$\mathrm{O}_{1} \mathrm{X} \mathrm{O}_{2}$}

Description:

$\mathrm{O}_{1}=$ Pretest

$\mathrm{O}_{2}=$ Posttest

$\mathrm{X}=$ Treatment (Learning by using media Chemistry Racing Challenge)

The instruments used in this study were validation sheets, student response questionnaire sheets, questionnaire sheets self-regulated learning, and test sheet. Data collection techniques were carried out in 3 ways, namely, 1) giving questionnaires to three validators through a Likert scale, 2) giving test questions related to acid-base material, 3) giving student response questionnaires, and self-regulated learning questionnaires. The data obtained were then analyzed with the following techniques.

\section{Product Validity}

Validity test using a Likert scale 1-5 with very bad to very good criteria. The questionnaire is given to 3 validators: two lecturers and one chemistry teacher. Validation rating scale is shown in Table 1.

Table 1. Validation Rating Scale

\begin{tabular}{cc}
\hline Score & Criteria \\
\hline 1 & Very Bad \\
2 & Pretty Good \\
3 & Good Enough \\
4 & Good \\
5 & Very Good \\
\hline
\end{tabular}

Based on these criteria, the chemistry racing challenge game is valid if the mode score reaches $\geq 3$.

\section{Product Practicality}

The practicality test uses percentage calculations that refer to students' responses to media questionnaires based on the Guttman scale shown in Table 2.

Table 2. Guttman Scale

\begin{tabular}{ccc}
\hline Answer & Score for negative statements & Score for positive statements \\
\hline Yes & 0 & 1 \\
No & 1 & 0
\end{tabular}

The practicality of learning media can be known through the following calculations:

$$
\mathrm{P}(\%)=\frac{\text { The number of positive responses }}{\text { The number of respondents }} \times 100 \%
$$

Furthermore, the percentage score obtained will be interpreted to find out the practicality of the media game Chemistry Racing Challange. The score interpretation is shown in Table 3. 
Table 3. Interpretation of Practicality Score

\begin{tabular}{cc}
\hline Percentage (\%) & Category \\
\hline $0-20$ & Not Practical \\
$21-40$ & Less Practical \\
$41-60$ & Practical Enough \\
$61-80$ & Practical \\
$81-100$ & Very Practical \\
\hline
\end{tabular}

Based on Table 3, the game Chemistry Racing Challenge is practically used as a learning media with an achievement percentage of $\geq 61 \%$.

\section{Product Effectiveness}

The effectiveness test refers to the results of learning outcomes and self-regulated learning. 1) Learning outcomes: The first is the SPSS program's test in a normality test. After the results of the pretest and posttest data normality tests are known, a hypothesis test using a nonparametric test with a 95\% confidence level. Next test to find out the results completeness of learning. Completeness of learning outcomes can be known through the calculation of classical completeness as follows:

Classical completeness $=\frac{\text { Number of students who complete }}{\text { The total number of students }} \times 100 \%$

Classical mastery is achieved if more than $\geq 75 \%$ of students have reached the KKM (value 70) (Azizah, 2016). 2) Questionnaire Self-regulated learning using the Likert scale shown in Table 4.

Table 4. Self-Regulated Learning Rating Scale

\begin{tabular}{cc}
\hline Score & Category \\
\hline 1 & Strongly disagree \\
2 & Disagree \\
3 & Not sure \\
4 & Agree \\
5 & Strongly agree \\
\hline
\end{tabular}

The test to determine self-regulated learning students uses the following calculation formula: The questionnaire is given after using the media chemistry racing challenge.

$$
\mathrm{P}(\%)=\frac{\text { The score obtained }}{\text { The maximum score }} \times 100 \%
$$

The results of students' self-regulated learning are categorized into several criteria. According to Arikunto in Rahmiyati (2017), if the percentage $(\mathrm{P}) \geq 0 \%$ is included in the very category low, $\mathrm{P} \geq 20.1 \%$ low category, $\mathrm{P} \geq 40.1 \%$ moderate category, $\mathrm{P} \geq 60.1 \%$ high category, $\mathrm{P} \geq 80.1 \%$ very high category.

\section{RESULTS AND DISCUSSION}

One of the factors that influence the learning process is the media used. Chemical game media that can be operated via Android and PC is intended to help class IX students of SMA MIPA study chemistry, especially acid-base material. From the literature study, it is known that students have difficulty studying chemistry. So there is no encouragement to learn because it cannot attract students' attention. Therefore, to help students increase their interest in learning and get a pleasant experience, it makes fun and interesting learning media innovation according to the age of high school students in general. The potential in developing games as learning media can be taken from this. Students get a pleasant experience in the learning process by 
using the game as a learning media. The next stage is making game designs or storyboards to make it easier to create game concepts developed to produce game products. Then, supervisor carries out a review process to find out the shortcomings, which will then be repaired. The results of review are presented in Table 5.

\section{Table 5. Review Results}

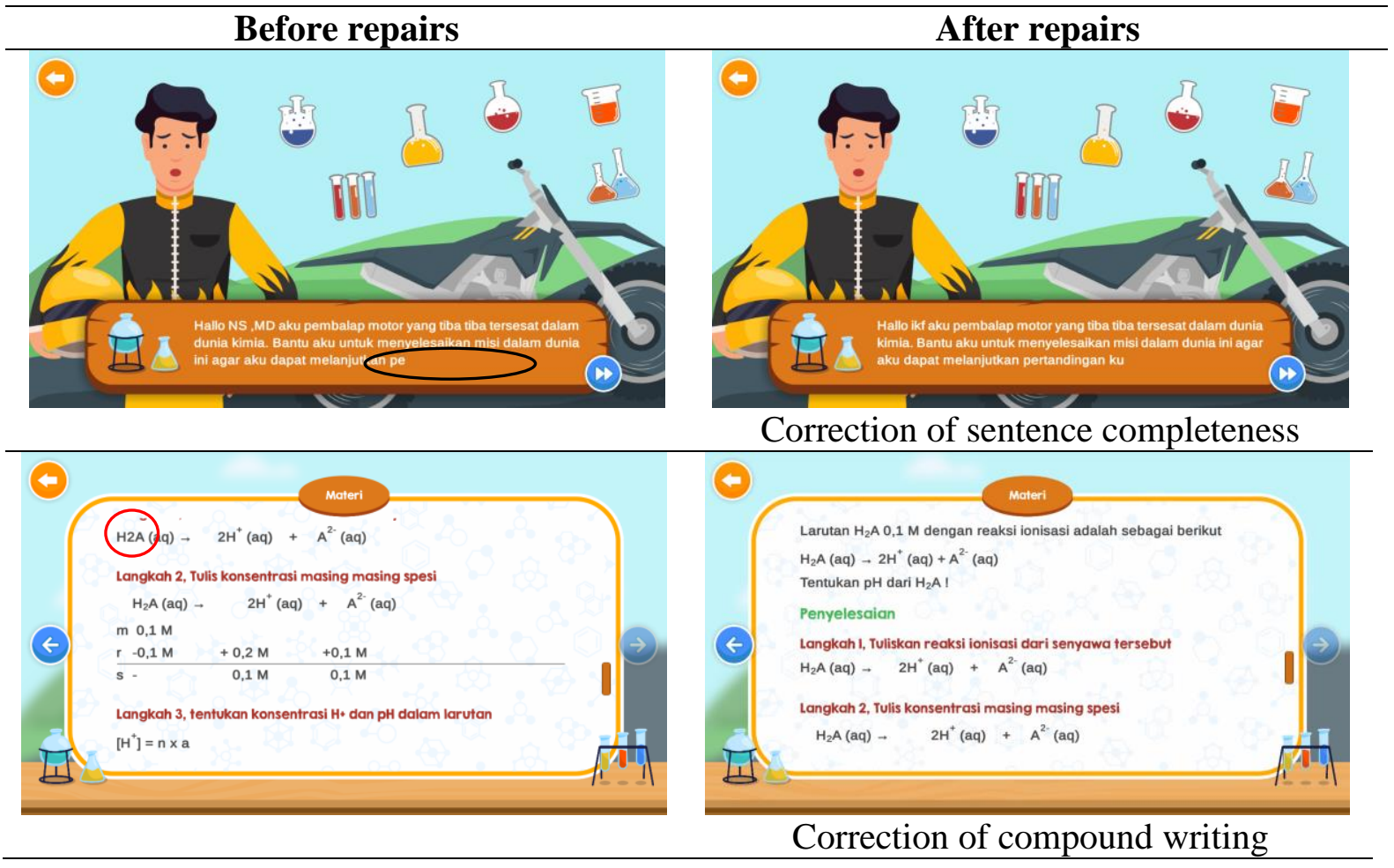

\section{The Validity}

After improving the game product from the results of the supervisor's review, then validation is carried out. Nieveen (1999) states that the criteria for the validity of a product are seen based on two things, namely content validity and construct validity. Content validity is determined by synchronizing the game's development and content. This is determined by three validators, where the instrument uses a Likert scale with very valid to very invalid assessment criteria. The data from the validation results are presented in Figure 2.

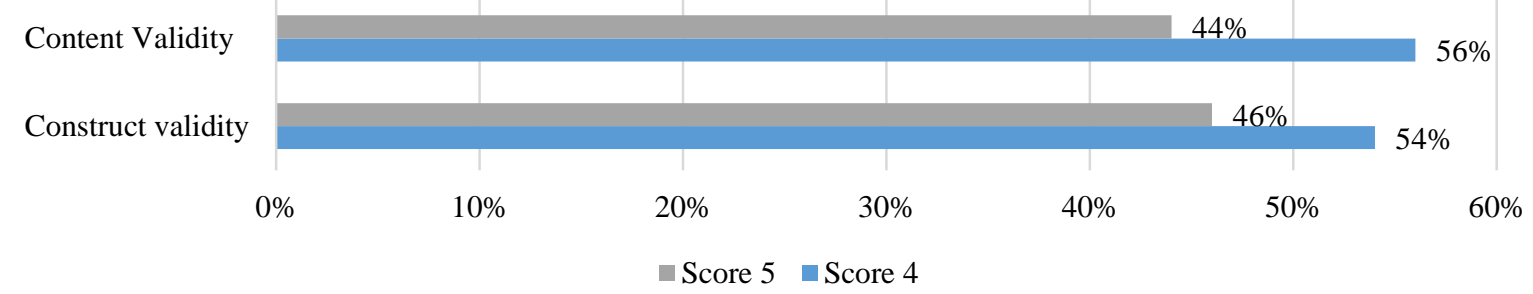

Figure 2. Validation result

Based on Figure 2, the validation results of the content aspect get an assessment from the validator, getting a percentage of $56 \%$ on a score of 4 . It can be seen that the game developed is said to be feasible because it gets a mode score of $\geq 3$. Namely, get mode four is included in the good criteria. Content validity includes two criteria, namely, 1) the correctness of the concept of chemistry in the game, 2) the suitability of the objectives with the material or questions in the game. According to Lutfi \& Hidayah (2019), things to consider in construct validity include 1) the game must meet the requirements of the game, 2) if it has a computer, 
then the computer aspect must be considered, as well as if it is based on Android and 3) the characteristics of the material to be studied be delivered. For construct validity, get a score of mode 4 , which is in the good category with $54 \%$. So it can be concluded that the game developed is declared valid by the validator.

\section{The Practicality}

Data was taken using a questionnaire given to students. The questionnaire contains user responses based on indicators that experts have categorized. Practicality criteria refer to the level of the product developed that is liked and can be used by students under normal conditions. The data on the practicality test results are presented in Table 6 .

Table 6. Student Response Questionnaire Results

\begin{tabular}{clcc}
\hline No & Purpose & Percentage \% & Category \\
\hline 1. & $\begin{array}{l}\text { Know the interest of learners in CRC } \\
\text { games }\end{array}$ & 91 & Very practical \\
2. & $\begin{array}{l}\text { Know the level of ease of use of the } \\
\text { game as a media of learning acid- } \\
\text { base material }\end{array}$ & 92 & Very practical \\
\hline
\end{tabular}

Based on Table 6, information was obtained that the Chemistry Racing Challenge game media received a positive response from students more than $61 \%$ for each goal. The first objective contained seven statements and received a positive response of $91 \%$. This shows that students agree that they are interested in CRC game media. This is following the learning function. According to Levie \& Lentz in Kusuma (2018), visual media can attract and direct students' attention to the material being studied. This has a high probability that students can remember the material well. In addition, Hossain in Nazar (2020) revealed that learning using smartphones is more fun for young people than studying with other devices such as books, laptops, or other available learning resources. The second goal is to get a response of $92 \%$. This shows that students agree that the media used is easy to operate. This is in line with Ewais's (2021) research, which states that respondents feel the ease of working with android-based media. There is an opinion that mobile phones in learning have several benefits in the learning process. One of them is increasing individual participation in learning activities and as a supporting tool in learning (Mohammadi et al., 2020).

\section{The Effectiveness}

The effectiveness of game media developed as learning media is shown by 1) Through learning outcomes tests by giving pretest and posttest, 2) Learning outcomes are supported by measuring self-regulated learning after being presented with game media.

\section{Learning outcomes}

The effectiveness of game media developed as learning media is shown through learning outcomes tests by giving pretest and posttest. The pretest and posttest results were tested for normality using IBM SPSS Statistics 25 software before testing the hypothesis. Sig value from the Shapiro-Wilk test, pretest data of 0.008 and postest 0.003 . Both are the same $<0.05$. The conclusion is that the data is not normally distributed. Because data does not qualify in parametric statistical testing, the hypothesis test uses a nonparametric statistical test, using the Wilcoxon test (Auliyah \& Flurenstin, 2016). The hypotheses used are as follows.

H0: There is no difference in learning outcomes between students' pretest and posttest scores after playing the game Chemistry Racing Challenge

Ha: There is a difference in learning outcomes between students' pretest and posttest scores after playing the game. Chemistry Racing Challenge 
The Wilcoxon test results are presented in Table 7.

Table 7. Wilcoxon Test Results

\begin{tabular}{lr}
\hline \multicolumn{2}{c}{ Postest - Pretest } \\
\hline$Z$ & $-3.540^{\mathrm{b}}$ \\
Asymp. Sig. (2-tailed) & .000 \\
\hline
\end{tabular}

Based on Table 7, the significance value refers to the Wilcoxon test of 0.000 . The result of the significance value is less than 0.05 , so $\mathrm{H} 0$ was rejected. So it can be concluded that there are differences in learning outcomes between pretest and posttest scores after playing the game media Chemistry Racing Challenge. The conclusion is in line with research conducted by Ismawati and Lutfi (2021), the conclusion is that there is a significant difference in learning outcomes between pretest scores and posttest scores after using game media. To get the test data analysis can be done with pretest and posttest. Students have completed learning by mastering the acid-base material by the learning objectives with individual mastery of 70 . They learn with the game Chemistry Racing Challenge obtained from increasing student learning outcomes. The following student learning outcomes are presented in Figure 3.

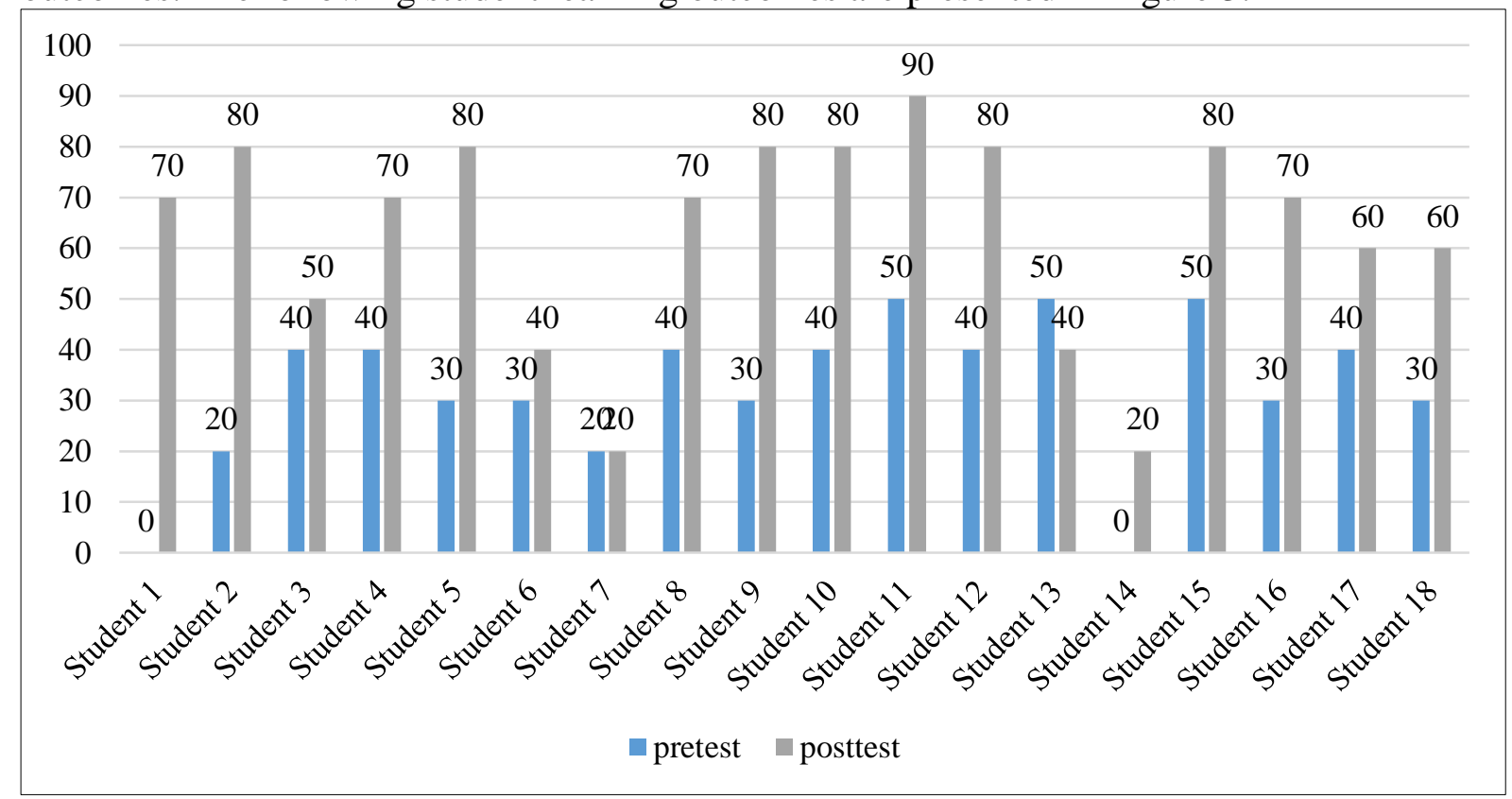

Figure 3. Graph of Improved Student Learning Outcomes

Based on Figure 3, it can be seen that in the pretest, the number of students who completed was 0 , or the classical percentage was $0 \%$. While students who did not complete as many as 18 people or by $100 \%$. The percentage obtained does not meet the percentage of classical completeness, which is $75 \geq \%$, so it has not been said to be complete on classical completeness.

The posttest data obtained that the number of students who completed was 11 people, or the classical percentage was $61 \%$. While the students who did not complete as many as seven people with a percentage of $39 \%$. The percentage obtained does not meet the minimum percentage, which is equal to individual completeness 70 and classical completeness $75 \%$, so that based on classical completeness, it is still not complete. Those are influenced by several things, including, when students play media games, most of them do not read the rules carefully first. They just open the submenu in the game without looking at the contents. Therefore, many small things but important information is missed when they enter the main sub-menu or play the game. So it is necessary to do more intensive assistance when students play media games. 


\section{Self-regulated learning (SRL)}

The SRL questionnaire adopted from Velayutham et al. (2011) has been modified to determine students' self-regulated learning. Questionnaires were used using the Likert scale with levels strongly disagree to strongly agree. According to Zimmerman, SRL has three components: metacognitive, motivational, and behavioral (Priyambodo, 2020). The motivation component is further divided into several aspects, namely, learning goal orientation, task value, and self-efficacy. These three things are related to involvement in SRL. The results of the SRL questionnaire data are presented in Table 8.

Table 8. Results of Student Self-Regulated Learning

\begin{tabular}{rccc}
\hline No & Component & Percentage $\mathbf{( \% )}$ & Category \\
\hline 1 & Learning goal orientation & 83 & Very high \\
2 & Task value & 88 & Very high \\
3 & Self Efficacy & 81 & Very high \\
4 & Self regulation & 83 & Very high \\
\hline
\end{tabular}

Learning goal orientation focuses on the learning process, understanding, and mastering the task. From Table 8, the results in learning goal orientation get a percentage of $83 \%$, which are included in the very high category. It shows that students have a high learning orientation when learning acid-base material using CRC game media. Previous research stated that the orientation of learning objectives could positively influence learning outcomes and student achievement (Velayutham et al., 2011). Other research states that individuals who have a high learning goal orientation will set their learning goals, commit to the goals set, and regulate their self-regulation (Cellar et al., 2010).

The task value got $88 \%$, which was included in the very high category. The task value is the most important thing on motivation (Tang \& Neber, 2008). In addition, the task value also has an important role in self-regulation. The task value is defined as "student evaluation of how interesting, important, and useful the task is" (Pintrich et al., 1993). This shows that students have a sense of caring about the assigned task. In other words, students consider it important to the questions contained in the media. CRC games. Previous research revealed that students with high task scores also use more learning strategies than students with low task scores (Neuville et al., 2007).

Self-efficacy gets $81 \%$, which falls into a very high category. Self-efficacy, according to Bandura, is defined as a person's ability to go through certain circumstances or achieve goals. In the learning process, learners with high self-efficacy then optimally have an increased sense of confidence in learning outcomes (Tus, 2020). This research aligns with previous research that states that high self-efficacy can affect learners' learning outcomes, optimizing their cognition and confidence to get a higher score (Zahro \& Surjanti, 2021). Other research reveals the benefits of digital learning, including learners' motivation, which can increase, learners get more benefits, and learners will be easier to use because they are familiar with digital-related things (Zwart et al., 2020).

Self-regulation gets results of $83 \%$, which falls into the category of very good. The purpose of providing questionnaires on this component of self-regulation is to measure learners' motivation in learning in school or outside of learning. It is important to know whether learners are concentrating during learning or giving up in the face of difficulty. It also determines the extent of their response to other tasks to complete them on time (Mutawah et al., 2021). This means that learners positively respond to their self-regulation, where they have good selfregulation during and after learning in class. 


\section{CONCLUSION}

Based on the research, it can be concluded that the Chemistry Racing Challenge game that was developed is suitable for use as a learning media on acid-base material because it has fulfilled the aspects of validity, practicality, and effectiveness. As for the ability self-regulated learning of students, the percentage results in the aspect of learning goal orientation, task value, self-efficacy, and self-regulation $\geq 80.1 \%$ are included in the very high category.

\section{RECOMMENDATION}

The next study expects teachers to accompany students better to ensure that learners have opened all submenus contained in the media. In addition, it is expected that more researchers will develop gaming media on other materials in chemistry lessons.

\section{REFERENCES}

Auliyah, A., \& Flurentin, E. (2016). Efektifitas Penggunaan Media Film Untuk Meningkatkan Empati Siswa Kelas Vii Smp. Jurnal Kajian Bimbingan Dan Konseling, 1(2), 19-26. https://doi.org/10.17977/um001v1i12016p019

Azizah, N. (2016). Pengembangan Lks Dan Penerapannya Dalam Pembelajaran Kooperatif Tipe Stad Untuk Meningkatkan Aktivitas Dan Hasil Belajar Kimia Siswa. Jurnal Pijar Mipa, 11(1), 60-64. https://doi.org/10.29303/jpm.v11i1.7

Boekaerts, M., \& Cascallar, E. (2006). How far have we moved toward the integration of theory and practice in self-regulation? Educational Psychology Review, 18(3), 199-210. https://doi.org/10.1007/s10648-006-9013-4

Cellar, D., Stuhlmacher, A., Young, S., Fisher, D., Adair, C., Haynes, S., Twichell, E., Arnold, K., Royer, K., Denning, B., \& Riester, D. (2010). Trait Goal Orientation, Self-Regulation, and Performance: A Meta-Analysis. Journal of Business and Psychology, 26(4), 467-483.

Chuang, T.-Y., \& Chen, W.-F. (2007). Effect of Computer-Based Video Games on Children: An Experimental Study. 2007 First IEEE International Workshop on Digital Game and Intelligent Toy Enhanced Learning (DIGITEL'07).

Dewi, I. K., \& Lutfi, A. (2021). Chem-Rox Games As A Learning Media For The Concept of Reduction and Oxidation Reactions Material to Increase Students Learning Motivation. Chemistry Education Practice, 4(1), 59. https://doi.org/10.29303/cep.v4i1.2397

Dwiningsih, K., Sukarmin, Nf., Muchlis, Nf., \& Rahma, P. T. (2018). Pengembangan Media Pembelajaran Kimia Menggunakan Media Laboratorium Virtual Berdasarkan Paradigma Pembelajaran Di Era Global. Kwangsan: Jurnal Teknologi Pendidikan, 6(2), 156-176. https://doi.org/10.31800/jtp.kw.v6n2.p156--176

Ewais, A., Hodrob, R., Maree, M., \& Jaradat, S. (2021). Mobile Learning Application for Helping Pupils in Learning Chemistry. International Journal of Interactive Mobile Technologies, 15(1), 105-118. https://doi.org/10.3991/IJIM.V15I01.11897

Hemayanti, K. L., Muderawan, I. W., \& Selamat, I. N. (2020). Analisis Minat Belajar Siswa Kelas Xi Mia Pada Mata Pelajaran Kimia. Jurnal Pendidikan Kimia Indonesia, 4(1), 20. https://doi.org/10.23887/jpk.v4i1.24060

Hidayah, R., \& Rahmanah, A. (2019). Kepraktisan Permainan Simple NOMIC Berbasis Android sebagai Media Pembelajaran pada Materi Tata Nama Senyawa Anorganik Sederhana. EduChemia (Jurnal Kimia Dan Pendidikan), 4(2), 195. https://doi.org/10.30870/educhemia.v4i2.5884

Lutfi, A., \& Hidayah, R. (2019). Media Permainan Kimia. UNESA University Press.

Maharani, P., \& Asyhari, A. (2020). Construct 2 Interactive Multimedia for Temperature and Heat Topic: A Multimedia Development for Senior High School Learning. Indonesian Journal of Science ..., 03(November), 336-346. https://doi.org/10.24042/ijsme.v4i1.8673

Merdekawati, K. (2013). Pengaruh Kemampuan Matematik Terhadap Prestasi Belajar Kimia. Jurnal Inovasi Dan Kewirausahaan, 2(1), 26-31. 
Mohammadi, M., Sarvestani, M. S., \& Nouroozi, S. (2020). Mobile Phone Use in Education and Learning by Faculty Members of Technical-Engineering Groups: Concurrent Mixed Methods Design. Frontiers in Education, 5(February), 1-9. https://doi.org/10.3389/feduc.2020.00016

Mutawah, M. A. Al, Thomas, R., \& Khine, M. S. (2021). Investigation into Self-regulation, Engagement in Learning Mathematics and Science and Achievement among Bahrain Secondary School Students. International Electronic Journal of Mathematics Education, 12(3), 633-653. https://doi.org/10.29333/iejme/639

Nazar, M., Putri, R. I. C., \& Puspita, K. (2020). Developing an android-based game for chemistry learners and its usability assessment. International Journal of Interactive Mobile Technologies, 14(15), 111-124. https://doi.org/10.3991/IJIM.V14I15.14351

Neuville, S., Frenay, M., \& Bourgeois, E. (2007). Task value, self-efficacy and goal orientations : performance among university students. Psychologica Belgica, 47(1/2), 95117.

Nieveen, N. (1999). Prototyping to Reach Product Quality. Design Approaches and Tools in Education and Training, 125-135. https://doi.org/10.1007/978-94-011-4255-7_10

Persico, D., \& Steffens, K. (2017). Self-regulated learning in technology enhanced learning environments. Technology Enhanced Learning: Research Themes, August 2015, 115116. https://doi.org/10.1007/978-3-319-02600-8_11

Pintrich, P. R., Smith, D. A. F., Garcia, T., \& Mckeachie, W. J. (1993). Reliability and Predictive Validity of the Motivated Strategies for Learning Questionnaire (Mslq). Educational and Psychological Measurement, 53(3), 801-813. https://doi.org/10.1177/0013164493053003024

Priyambodo, E. (2020). Penerapan Multimedia Based Learning (Mbl) Pada Mata Pelajaran Kimia Untuk Meningkatkan Self-Regulated Learning (Srl) Siswa Sma N 1 Sleman. Jurnal Inovasi Pendidikan Kimia, 14(1), 2460-2467.

Rahmiyati, A. (2017). Pengaruh Self Regulated Learning Terhadap Prestasi. SOSIO DIDAKTIKA : Social Science Education Journal, 5(1), 8-14.

Rosito, A. C. (2018). Kepribadian dan Self-Regulated Learning. Jurnal Psikologi, 45(3), 189. https://doi.org/10.22146/jpsi.28530

Sahlan, F., Haetami, A., \& Marhadi, M. A. (2016). Identifikasi Kesulitan Belajar Siswa Pada Materi. Jurnal Pendidikan Kimia FKIP Universitas Halu Oleo, 5(7), 58-69.

Sugiyono, P. D. (2016). Metode Penelitian Pendidikan (Pendekatan Kuantitatif, Kualitatif, dan $R \& D)$. ALFABETA.

Tang, M., \& Neber, H. (2008). Motivation and self-regulated science learning in highachieving students: Differences related to nation, gender, and grade-level. High Ability Studies, 19(2), 103-116. https://doi.org/10.1080/13598130802503959

Tus, J. (2020). Self-Concept, Self-Esteem, Self-Efficacy and Academic Performance of the Henior High School Students. November. https://doi.org/10.6084/m9.figshare.13174991.v1

Velayutham, S., Aldridge, J., \& Fraser, B. (2011). Development and validation of an instrument to measure students' motivation and self-regulation in science learning. International Journal of Science Education, 33(15), 2159-2179. https://doi.org/10.1080/09500693.2010.541529

Yulianti, P., Sano, A., \& Ifdil, I. (2016). Self Regulated Learning Siswa Dilihat dari Hasil Belajar. Jurnal EDUCATIO Jurnal Pendidikan Indonesia, 2(1), 98-102. https://doi.org/10.29210/12016240

Zahro, M., \& Surjanti, J. (2021). Pengaruh Self Regulated Learning dan Self Efficacy Terhadap Hasil Belajar Ekonomi Peserta Didik dalam Pembelajaran Daring di Era Covid-19. Edukatif: Jurnal Ilmu Pendidikan, 3(4), 1470-1479. 
https://edukatif.org/index.php/edukatif/article/view/560

Zwart, D. P., Noroozi, O., Van Luit, J. E. H., Goei, S. L., \& Nieuwenhuis, A. (2020). Effects of Digital Learning Materials on nursing students' mathematics learning, self-efficacy, and task value in vocational education. Nurse Education in Practice, 44(May 2019), 102755. https://doi.org/10.1016/j.nepr.2020.102755 